\title{
CONTRIBUTIONS TO THE KNOWLEDGE OF THE STRUCTURE AND ECOLOGICAL INDICES OF COLEOPTERS POPULATIONS IN THE WALNUT ORCHARDS
}

\author{
Ionel Perju ${ }^{1}$, Mihai Tălmaciu ${ }^{1}$, Nela Tălmaciu ${ }^{1}$, Monica Herea ${ }^{1, *}$ \\ ${ }^{1}$ University of Life Science „Ion Ionescu de la Brad” from Iasi, Iași, Romania
}

Current Trends in

Natural Sciences

\begin{abstract}
The observations were made during 2019 and 2020 in a walnut orchard from Sârca farm, in Iasi County.

The material was collected using Barber-type soil traps during the two years of research, at a time interval between 10 and 14 days from May to August inclusive, thus integrating a number of 10 or 8 harvests in 2019 and 2020.

The biological material collected was cleaned of plant debris and then prepared for identification, at the level of order, and for the specimens of beetles we made the determination up to the species level.

From the analysis of the collected material it results that the collected specimens belong to the Hexapoda Class, the Coleoptera order. The species of coleopters insects collected belong to the species: Anysodactilus binotatus, Harpalus pubescens, Otiorrhynchus pinastri, Dermestes laniarius, Harpalus tenebrosus, Amara crenata, Paramalus paralelipipedus, Colodera aethiops, Phyllotreta attra, Harpalus calceatus
\end{abstract}

Keywords: Barber traps, coleopters fauna, walnul orchard.

\section{INTRODUCTION}

Among the most important insect families belonging to both the useful and harmful entomofauna belong to the Order of Insecta (Coleoptera), which includes species spread around the globe. The species of this order have a trophic regime to a large extent entomophagous, but there are also species of mixed-phage or phytophagous (few species) (Granja,2013). In agricultural crops, in fruit plantations and even in forest areas, many of the species are particularly important ecological indicators, responding immediately to some human interventions, such as pesticides, which cause the paralysis or even the death of adult insects or larvae at shortly after treatment.

This paper presents some research results on the bumblebee population of a walnut tree plantation, where the fruits are destined for consumption.

\section{MATERIALS AND METHODS}

The material was collected during to 2019-2020, with the help of soil trap type Barber.

In the stationary from Sarca- Iași, there were effectuated a number of 10 harvesting in 2019 at the followings dates: $18.05 ; 24.05 ; 07.06 ; 18.06 ; 22.06 ; 06.07 ; 21.07 ; 02.08 ; 11.08$ and 30.08 and 8 harvesting in 2020 as followings dates: $25.04 ; 04.05 ; 15.05 ; 25.05 ; 08.06 ; 15.06 ; 04.07$ and 28.07. 
The species of coleopters entomofauna were colected with the help of the soil traps type Barber using the salt solution with $20 \%$. (Talmaciu, 2011) The biological materials from the trap were collected every 7-10 days. At each harverst, the solution was completed or replaced, if necesary. The collected material was brought in the laboratory where we separated the species and determinated them.

In the walnut orchards from Sarca, in the research period there were placed a number of 42 Barber soil traps. Depending on the number of collections each year, and depending on the climatic conditions and the state of the traps, in 2019, we are realize 10 harvesting of the biological material, and we ware collected only 371 traps, while in 2020 in the 8 harvests we have totalized a number of 332 of traps.

\section{RESULTS AND DISCUSSIONS}

In 2019, from walnut plantation belonging to farm from Sarca, Iași country, there were effectuated a number of 10 harvesting, there were collected 15 species of coleopters (Table 1).

In 2019 the species with largest number of sample collected were: Harpalus calceatus (225samples) Anysodactilus binotatus (150 samples) Harpalus tenebrosus (129 samples) Harpalus distinguendus (100 samples) Harpalus pubescens (96 samples) Harpalus griseus (64 samples) Otiorrhynchus pinastri (33 samples) Harpalus tardus(17 samples).

The research from Sârca Farm, in 2020 (table 2), in the walnut orchards the largest number of samples were collected was belonging at: Anysodactilus binotatus (640samples), Harpalus distinguendus (477 samples), Dermestes laniarius (323 samples), Otiorrhynchus pinastri (179 samples), Harpalus calceatus ( 115 samples), Harpalus tenebrosus (93 samples), Metabletus truncatelus (62 samples), Tachyusa coarctata (60 samples), Oxypora vittata (58 samples), Epicometis hirta (36 samples), Amara crenata (35 samples), Paramalus paralelipipedus (35 samples), Colodera aethiops (34 samples).

The taxonomic-ecological aspect (Reiter,1908) of an agroecosystem is the first step towards knowing its structure. To determine the structure and dynamics of a biocenosis, of the collected material undergoes a mathematical analysis, estimating a series of indicators that highlight the characteristics of the ecosystem. To achieve this goal, the sinecological analysis of Coleoptera fauna from the walnut orchards was performed to assess the ratio of each species in the analyzed biocenosis.

During the research period 2019-2020 the data obtained from the Barber method was presented in Table 1 for 2019 and Table 2, for 2020.

The material obtained from the observations was mathematically processed to obtain a value of ecological indicators (Herea, 2010, 2011) (table3 and table 4): abundance (A), dominance (D), constancy $(\mathrm{C})$ and ecological significance index (W).

The abundance (A) in 2019 had values ranging between 225 specimens (Harpalus calceatus) and 3 specimens (Harpalus aeneus). In 2020 abundance recorded values between 640 (Anysodactilus binotatus) and 11 (Phyllotreta attra).

Dominance (D) according to the calculated percentage value, the species is distributed in dominant classes. 
Current Trends in Natural Sciences

Vol. 10, Issue 19, pp.220-225, 2021

https://doi.org/10.47068/ctns.2021.v10i19.029

Current Trends in Natural Sciences (on-line)

ISSN: 2284-953X

Current Trends in Natural Sciences (CD-Rom)

ISSN: 2284-9521

ISSN-L: 2284-9521

ISSN-L: 2284-9521

Table 1. The structure and abundance species of coleopters epigeous entomofauna collecting from the walnut orchard belonging to farm of Sarca, in 2019

\begin{tabular}{|l|l|c|c|c|c|c|c|c|c|c|c|c|}
\hline No & Species & $\mathbf{1 8 . 0 5}$ & $\mathbf{2 4 . 0 5}$ & $\mathbf{0 7 . 0 6}$ & $\mathbf{1 8 . 0 6}$ & $\mathbf{2 2 . 0 6}$ & $\mathbf{0 6 . 0 7}$ & $\mathbf{2 1 . 0 7}$ & $\mathbf{0 2 . 0 8}$ & $\mathbf{1 1 . 0 8}$ & $\mathbf{3 0 . 0 8}$ & Total \\
\hline 1. & Harpalus calceatus & 29 & 56 & 32 & 32 & 17 & 33 & 5 & 9 & & 12 & 225 \\
\hline 2. & $\begin{array}{l}\text { Anysodactilus } \\
\text { binotatus }\end{array}$ & 22 & 49 & 24 & 29 & & 2 & 22 & & 1 & 1 & 150 \\
\hline 3. & $\begin{array}{l}\text { Harpalus tenebros } \\
\text { us }\end{array}$ & 42 & 12 & & 30 & 28 & 17 & 10 & & & 129 \\
\hline 4. & $\begin{array}{l}\text { Harpalus } \\
\text { distinguendus }\end{array}$ & 11 & 11 & 12 & 20 & 11 & 4 & 1 & 6 & 22 & 2 & 100 \\
\hline 5. & Harpalus pubescens & 11 & 14 & 23 & 2 & & 17 & 17 & 7 & 1 & 4 & 96 \\
\hline 6. & Harpalus griseus & 11 & 27 & 10 & & & 2 & 2 & 12 & & & 64 \\
\hline 7. & $\begin{array}{l}\text { Otiorrhynchus } \\
\text { pinastri }\end{array}$ & 3 & 10 & 9 & & 3 & 4 & 4 & & 1 & & 33 \\
\hline 8. & Harpalus tardus & 4 & & & & & 6 & 7 & & & & 17 \\
\hline 9. & Oxypora vittata & & 6 & & & & & & & & 1 & 7 \\
\hline 10. & $\begin{array}{l}\text { Metabletus } \\
\text { truncatelus }\end{array}$ & 1 & 1 & 3 & 1 & & & & & & & 6 \\
\hline 11. & Hister purpurascens & & & & & 3 & 3 & & & & & 6 \\
\hline 12. & $\begin{array}{l}\text { Coccinella 7 } \\
\text { punctata }\end{array}$ & & 3 & & & & & & 2 & & 1 & 6 \\
\hline 13. & Harpalus azureus & 1 & & & & & & 1 & 3 & & & 5 \\
\hline 14. & Scymnus auritus & & 1 & & 2 & & & & & & 1 & 4 \\
\hline 15. & Harpalus aeneus & & 1 & 1 & & & 1 & & & & & 3 \\
\hline
\end{tabular}

Table 2. The structure and abundance species of coleopters epigeous entomofauna collecting from the walnut orchard belonging to Sarca farm, in 2020

\begin{tabular}{|l|l|l|l|l|l|l|l|l|l|l|}
\hline No. & Species & $\mathbf{2 5 . 0 4}$ & $\mathbf{0 4 . 0 5}$ & $\mathbf{1 5 . 0 5}$ & $\mathbf{2 5 . 0 5}$ & $\mathbf{0 8 . 0 6}$ & $\mathbf{1 5 . 0 6}$ & $\mathbf{0 4 . 0 7}$ & $\mathbf{2 8 . 0 7}$ & Total \\
\hline 1. & Anysodactilus binotatus & 89 & 187 & 229 & 49 & 2 & 27 & 13 & 44 & 640 \\
\hline 2. & Harpalus distinguendus & 74 & 172 & 115 & 54 & 2 & 19 & 41 & & 477 \\
\hline 3. & Dermestes laniarius & 33 & 76 & 111 & 22 & 52 & 14 & & 15 & 323 \\
\hline 4. & Otiorrhynchus pinastri & 51 & & 5 & 11 & 42 & 46 & 13 & 11 & 179 \\
\hline 5. & Harpalus calceatus & 1 & 11 & 39 & 6 & 2 & 25 & 5 & 26 & 115 \\
\hline 6. & Harpalus tenebrosus & 48 & & 4 & 20 & & & 21 & & 93 \\
\hline 7. & Metabletus truncatelus & 7 & & 7 & 11 & 6 & 16 & 4 & & 62 \\
\hline 8. & Tachyusa coarctata & & 16 & 8 & & 14 & & 22 & & 60 \\
\hline 9. & Oxypora vittata & & 8 & & 7 & 14 & 6 & 23 & & 58 \\
\hline 10. & Epicometis hirta & 17 & & 14 & & & 5 & & & 36 \\
\hline 11. & Amara crenata & 8 & 5 & & 4 & 18 & & & & 35 \\
\hline 12. & $\begin{array}{l}\text { Paramalus } \\
\text { paralelipipedus }\end{array}$ & & 10 & & 18 & 7 & & & & 35 \\
\hline 13. & Colodera aethiops & & 11 & & & & & & 23 & 34 \\
\hline 14. & Harpalus griseus & & & 9 & 6 & & & & 10 & 25 \\
\hline 15. & Harpalus pubescens & & & 5 & 5 & & & 10 & & 20 \\
\hline 16. & Aphtona euphorbiae & 4 & 10 & 5 & & & & & & 19 \\
\hline 17. & Harpalus tardus & & & & & 14 & 3 & & & 17 \\
\hline 18. & Monotoma picipes & 9 & & & 6 & & & & & 15 \\
\hline 19. & Harpalus aeneus & 2 & 5 & & & & & 2 & 4 & 13 \\
\hline 20. & Sipalia circelaris & & & & & & & 13 & & 13 \\
\hline 21. & Epurea obsoleta & 12 & & & & & & & & 12 \\
\hline 22. & Phylotreta atra & & & & & & & 11 & & 11 \\
\hline
\end{tabular}




\section{Current Trends in Natural Sciences}

Vol. 10, Issue 19, pp.220-225, 2021

https://doi.org/10.47068/ctns.2021.v10i19.029

Current Trends in Natural Sciences (on-line)

Table 3. Structure, abundance, dominance, constant and ecological index of species collected in 2019

\begin{tabular}{|c|l|l|l|l|l|}
\hline No. & Species & \multicolumn{1}{|c|}{ A } & \multicolumn{1}{|c|}{ D } & \multicolumn{1}{|c|}{ C } \\
\hline 1. & Harpalus pubescens & 96 & 11.307 & 10.609 & 1.199 \\
\hline 2. & Harpalus calceatus & 225 & 26.501 & 44.878 & 11.893 \\
\hline 3. & Harpalus distinguendus & 100 & 11.778 & 15363 & 1.809 \\
\hline 4. & Anysodactilus binotatus & 150 & 17.667 & 25.47 & 4.499 \\
\hline 5. & Harpalus griseus & 64 & 7.538 & 4.830 & 0.36 \\
\hline 6. & Harpalus azureus & 5 & 0.588 & 0.040 & 0.02 \\
\hline 7. & Harpalus tenebrosus & 129 & 15.194 & 15.646 & 2.377 \\
\hline 8. & Harpalus tardus & 17 & 2.002 & 0.504 & 0.01 \\
\hline 9. & Harpalus aeneus & 3 & 0.353 & 0.024 & 0.008 \\
\hline 10. & Metabletus truncatelus & 6 & 0.706 & 0.080 & 0.0056 \\
\hline 11. & Hister purpurascens & 6 & 0.706 & 0.032 & 0.022 \\
\hline 12. & Otiorrhynchus pinastri & 33 & 3.886 & 2.134 & 0.082 \\
\hline 13. & Scymnus auritus & 4 & 0.471 & 0.043 & 0.002 \\
\hline 14. & Coccinella 7 punctata & 6 & 0.706 & 0.097 & 0.006 \\
\hline 15. & Oxypora vittata & 7 & 0.824 & 0.056 & 0.046 \\
\hline Total & & 849 & - & - & - \\
\hline
\end{tabular}

Table 4. Structure, abundance, dominance, constant and ecological index of species collected in 2020

\begin{tabular}{|c|l|l|l|l|l|}
\hline No. & Species & \multicolumn{1}{|c|}{ A } & \multicolumn{1}{c|}{ D } & \multicolumn{1}{c|}{ C } & \multicolumn{1}{c|}{ W } \\
\hline 1. & Harpalus pubescens & 20 & 0.835 & 0.411 & 0.0034 \\
\hline 2. & Harpalus calceatus & 115 & 4.805 & 6.947 & 0.333 \\
\hline 3. & Harpalus distinguendus & 477 & 19.933 & 47.209 & 9.41 \\
\hline 4. & Anysodactilus binotatus & 640 & 26.744 & 78.971 & 21.12 \\
\hline 5. & Harpalus griseus & 25 & 1.044 & 0.578 & 0.006 \\
\hline 6. & Harpalus tenebrosus & 93 & 3.886 & 4.303 & 0.167 \\
\hline 7. & Harpalus tardus & 17 & 0.71 & 0.240 & 0.003 \\
\hline 8. & Harpalus aeneus & 13 & 0.543 & 0.2 & 0.001 \\
\hline 9. & Metabletus truncatelus & 62 & 2.59 & 3.347 & 0.086 \\
\hline 10. & Otiorrhynchus pinastri & 179 & 7.48 & 15.645 & 1.169 \\
\hline $1 .$. & Tachyusa coarctata & 60 & 2.507 & 2.853 & 0.07 \\
\hline 12. & Aphtona euphorbiae & 19 & 0.793 & 0.39 & 0.003 \\
\hline 13. & Dermestes laniarius & 323 & 13.497 & 35.704 & 4.815 \\
\hline 14. & Amara crenata & 35 & 1.462 & 1.259 & 0.02 \\
\hline 15. & Epurea obsoleta & 12 & 0.501 & 0.107 & 0.001 \\
\hline 16. & Oxypora vittata & 58 & 2.423 & 2.683 & 0.06 \\
\hline 17. & Colodera aethiops & 34 & 1.42 & 0.83 & 0.016 \\
\hline 18. & Epicometis hirta & 36 & 1.504 & 1.11 & 0.02 \\
\hline 19. & Monotoma picipes & 15 & 0.626 & 0.25 & 0.002 \\
\hline 20. & Sipalia circelaris & 13 & 0.543 & 0.167 & 0.001 \\
\hline 21. & Paramalus paralelipipedus & 35 & 1.462 & 1.214 & 0.02 \\
\hline 22. & Phylotreta atra & 11 & 0.459 & 0.127 & 0.001 \\
\hline 23. & Aleochara moerens & 20 & 0.835 & 0.282 & 0.0036 \\
\hline 24. & Aleochara ruficornis & 19 & 0.793 & 0.293 & 0.0033 \\
\hline 25. & Aleochara laevigata & 12 & 0.501 & 0.123 & 0.002 \\
\hline 26. & Onthophagus semicornis & 25 & 1.044 & 0.385 & 0.003 \\
\hline Total & & 2368 & - & - & - \\
\hline & & & & \\
\hline
\end{tabular}


In the year 2019 there were 7 species are subordinated, they had values below 1.1\%; 2 species are subdomains and had values between 2.1-5\% 1 species is dominant with the value ranging from 5.1$10.0 \%, 5$ species are eudominant with the value over $10 \%$

In 2020 there were: 11 species were subordinated, they had values below 1.1\%; 5 species are subdomains and had values between $2.1-5 \%$; 1 species is dominant with a value in the range of 5.1$10.0 \% ; 3$ species are eudominant with the value above $10 \%$

Constance (C) - depending on the value of this indicator, the species is distributed in the following classes:

In 2019, the species mostly collected were accidental species, only two species were included in the accessory category.

In 2020, the species recorded on which most of the calculations were made fall into the group of accidental species, only three species are included in the accessory category, and only one species is constant.

Ecological significance index (W) is the relationship between structural (C) and productive (D). Depending on the percentage value calculated in the two years of study, the species are distributed in the following classes: with values below $0.1 \%$ of the by-species; with values between $0.1-1.0 \%$ of the accessory species; with values between 1.1 and $5.0 \%$ of the accessory species; with values between $5.1-10.0 \%$ of the characteristic species; with values above $10.0 \%$ of the characteristic species.

Regarding the common species gathering process in 2019-2020 as it follows: Harpalus calceatus (225samples in 2019) ( 115 samples in 2020) Anysodactilus binotatus (150 samples in 2019) (640samples in 2020) Harpalus tenebrosus (129 samples in 2019) (93 samples in 2020) Harpalus distinguendus (100 samples in 2019) (477 samples in 2020) .

\section{CONCLUSIONS}

1. The soil traps of Barber type were used for collecting of the entomofauna witch moves on the soil surface, out of which the coleoptera species were kept, these traps worked from May to September.

2. There were effected a number of 10 harvesting in the year 2019, and 8 harvesting in 2020 after taking the collected material from the traps and simultaneously it was change or completed the solution of formol of 3-4\% concentration.

3. In 2019 it was collected in totality 849 samples of Coleoptera belonging to: Harpalus calceatus, Anysodactilus binotatus, Harpalus tenebrosus, Harpalus distinguendus, Harpalus pubescens, Harpalus griseus, Otiorrhynchus pinastri, Harpalus tardus.

4. In 2020 it was collected in totality 2368 samples of Coleoptera belonging to: Anysodactilus binotatus, Harpalus distinguendus, Dermestes laniarius, Otiorrhynchus pinastri, Harpalus calceatus, Harpalus tenebrosus, Metabletus truncatelus, Tachyusa coarctata, Oxypora vittata, Epicometis hirta, Amara crenata, Paramalus paralelipipedus, Colodera aethiops.

\section{REFERENCES}

Beşleagă, R., Tălmaciu, M., Cârdei, E., Tălmaciu, N., Corneanu, G. (2013) The effect of phytoprotection programs on the control of the main apple pests. Cercetări Agronomice în Moldova,1 (153), 83-88

Ganja, V., Rubţov S. (2013) Study of the microbiota and comparative analysis of nuts from different regions of Moldova. Conferinţa Tehnico-Ştiinţifică, UTM,-Chişinău : Tehnica - UTM, 33-39 


\section{Current Trends in Natural Sciences}

Vol. 10, Issue 19, pp.220-225, 2021

https://doi.org/10.47068/ctns.2021.v10i19.029

Current Trends in Natural Sciences (on-line)

ISSN: 2284-953X

Current Trends in Natural Sciences (CD-Rom)

ISSN: 2284-9521

ISSN-L: 2284-9521

ISSN-L: 2284-9521

Herea, M., Tălmaciu, M., Tălmaciu N. (2010) Contributions to the knowledge of fauna of beetles (order Coleoptera) in some ecosystems of sweet cherry and sour cherry in Eastern Romania. Analele Universităţii din Craiova, seria Horticultura, Ed. Universitaria, XV (XLXI), 285-290.

Herea, M., Tălmaciu, M., Tălmaciu, N. (2011) Research on knowledge of species of insects belonging useful fauna in some cherry orchards from Iaşi County Lucrări ştiinţifice, Ed. „Ion Ionescu de la Brad” Iaşi, Horticultură, 54, 116-120.

Talmaciu, M., Talmaciu, N., Herea,, M. (2011) Research on the Population Structure, Dynamics, and Abundance of Coleoptera Species in Sweet Cherry and Sour Cherry Plantations. XXVIII International horticultural congress on science and horticulture for people (IHC2010): International symposium on plant protection Book Series: Acta Horticulturae ,917, 119-124

Reitter, E. (1908) Fauna Germanica. Die Käfer des Deutschen Reiches Band I, Stuttgart. 